\title{
Examining the role of institutional support in enhancing smallholder oilseed producers' adaptability to climate change in Limpopo Province, South Africa ${ }^{\text {it }}$
}

\author{
Priscilla Ntuchu Kephe ${ }^{1,2, *}$, Brilliant Mareme Petja ${ }^{1,2,3}$ and Kingsley Kwabena Ayisi ${ }^{2}$ \\ ${ }^{1}$ Department of Geography and Environmental Studies, University of Limpopo, Polokwane, South Africa \\ 2 Risk and Vulnerability Science Centre, University of Limpopo, Sovenga, South Africa \\ ${ }^{3}$ Water Research Commission, Pretoria, South Africa
}

Received 5 October 2020 - Accepted 6 January 2021

\begin{abstract}
Smallholder oilseed production constitutes a crucial component of rural economies and continues to face the consequences of a changing climate despite the increased levels of vulnerability. This paper assesses how smallholder oilseed farmers' adaptive capacity in Limpopo is enhanced through various institutional support schemes within the context of increased climate extremes and their need to sustain production. Six hundred farmers were interviewed across three agro-ecological zones of Limpopo Province. Results show that some of the institutions' current operations aimed at providing support to farmers do not adequately satisfy the farmers' needs. A strong linear relationship was observed between the number of support types received by farmers and grain yield, suggesting that farmers who received more support types were relatively less vulnerable. Educational support is ranked as the most significant contributor to enhancing farmers' adaptive capacity. This emphasizes the need for proper linkages between farmers' choices of adaptive methods and the types of support needed. Therefore, this study provided a diagnosis of the gaps in essential types of institutional support needed to increase farmers' resilience, which can be used as an input to beef up the policy and positioning to improve the adaptive capacity.
\end{abstract}

Keywords: adaptive capacity / climate change / institutional support / smallholder farming

Résumé - Examen du rôle du soutien institutionnel dans le renforcement de l'adaptabilité des petits producteurs d'oléagineux face au changement climatique dans la province de Limpopo, en Afrique du Sud. La production d'oléagineux par les petits exploitants constitue un élément crucial des économies rurales et continue à faire face aux conséquences du changement climatique malgré une vulnérabilité accrue. Cet article évalue comment la capacité d'adaptation des petits producteurs d'oléagineux du Limpopo est renforcée par divers programmes de soutien institutionnel dans le contexte d'une augmentation des phénomènes climatiques extrêmes et de leur besoin de maintenir la production. 600 agriculteurs ont été interrogés dans trois zones agro-écologiques de la province du Limpopo. Les résultats montrent que certaines des opérations actuelles des institutions visant à fournir un soutien aux agriculteurs ne répondent pas de manière adéquate aux besoins de ces derniers. Une forte relation linéaire a été observée entre le nombre de types d'aide reçus par les agriculteurs et le rendement, ce qui suggère que les agriculteurs qui ont reçu plus de types d'aides sont relativement moins vulnérables. L'aide à la formation est considérée comme le facteur le plus important pour améliorer la capacité d'adaptation des agriculteurs. Cela souligne la nécessité d'établir des liens appropriés entre les choix des agriculteurs en matière de méthodes d'adaptation et les types de soutien nécessaires. Cette étude a donc permis de diagnostiquer les lacunes des principaux types de soutiens institutionnels nécessaires pour accroître la résilience des agriculteurs, qui peuvent être utilisés pour renforcer la politique et le positionnement en vue d'améliorer leur capacité d'adaptation.

Mots clés : capacité d'adaptation / changement climatique / soutien institutionnel / petites exploitations agricoles

\footnotetext{
is Contribution to the Topical Issue "Creating new oil \& protein crop value chains / Construire de nouvelles filières oléoprotéagineuses".

*Correspondence: kprissy@gmail.com
} 


\section{Introduction}

Climate change continues to exert more pressure on smallholder farmers despite their persistence to continue to sustain agricultural production. Farmers in the summer rainfall areas in South Africa, particularly those in the Limpopo Province, have not been spared. A timeline of incidences of extreme drought events in the past four decades includes those experienced in 1982/83, 1987/88, 1991/92, 1994/95, 2002/03, 2008/09, and 2015/16 rainfall seasons (Agricultural disaster management policy, 2011; Bureau for Food and Agricultural Policy (BFAP), 2016) and severe floods since the 1920s (e.g., 1923, 1940, 1955, 1967, 1980, $2000,2011,2013,2014,2015)$ coupled with bushfires all of which impede productivity. Unlike their commercial counterparts, smallholder farmers face more significant challenges in adapting to climate change. This is because of factors such as low incomes, low levels of education, weak institutions, lack of markets and infrastructure, and an already-degraded ecosystem (Osbahr et al., 2010). Their vulnerability is heightened by poor economic development and low adaptive capacity (International Fund for Agricultural Development (IFAD), 2008). Besides climate change, other challenges facing farmers in the Limpopo Province have been well documented by studies such as Makhura (2002), Mpandeli and Maponya (2014), Mpandeli et al. (2015). They cite constraints such as inadequate access to productive resources, the high price of production inputs such as herbicides and fertilizers, lack of assets, market information, market access and cost of transport. These constraints already increase the vulnerability of these farmers before the addition of climate change effects into the picture. Mpandeli (2006) further notes that these challenges facing resource-poor farmers hinder agricultural development and climate change adaptation processes in Limpopo and other provinces in the South Africa such as the Eastern Cape, Mpumalanga, and Free State.

In light of the changing climate and its impacts on rain-fed agriculture, South Africa is no different from other countries with regards to the threat of climate change on the food security of the country (Human Science Research Council (HSRC), 2014). This situation presents a significant obstacle to achieving the New Sustainable Development Goals (SDGs) because the adverse effects of climate change undermine the countries capability to achieve these goals. The SDGs aim to encourage development by improving social and economic conditions, eliminating poverty and hunger and promoting environmental sustainability (United Nations Development Programme (UNDP), 2015).

In Limpopo Province, agriculture is one of the major cornerstones of the economy and the smallholder farmers are regarded as the drivers of rural economic development (Limpopo Department of Agriculture (LDA), 2012). Farmers tend to have inherent low adaptive capacity because of low technological inputs and know-how, limited access to climate information, and lack of other essential farming resources (Thamaga-Chitja and Morojele, 2014, Mpandeli et al., 2015). Climate change interventions and support services, where accessible, provide an opportunity for the farmers to withstand the climatic challenges, thereby strengthening their capacity to enhance agricultural productivity (Cherotich et al., 2012).

Several proponents have called for smallholder farming support, claiming that this will reduce inequality and poverty in African and Asian countries (Lowder et al., 2016). However, much of the debate on improving agricultural productivity and food security in marginal areas of South Africa has targeted mostly smallholder irrigation schemes (SIS) (Mwadzingeni et al., 2020), and less attention is paid to the performance of other support types from various institutions. Some of such studies show a trend of poor performance affecting SISs in South Africa and attribute such performances to poor institutional integration, consequently impacting service delivery (e.g., Ncube, 2017). Ncube (2017) looked at extension services and the performance of SIS and concluded that the current cooperative agricultural extension and irrigation operations fail to meet the needs of farmers. For extension to be effective, it should be able to mobilize communities' social capital to enable farmers to either benefit from synergies or make it easier to train and share information (Ncube, 2017). Previous studies, such as those of Mnkeni et al. (2010), shared similar findings and reported that Tugela Ferry and Zanyokwe irrigation schemes have weak organizational and institutional arrangements that affect their productivity and overall performance. Van Koppen et al. (2017) attributed the poor status of infrastructure and low utilization of irrigation schemes to poor focus on institutional and social factors. Mwadzingeni et al. (2020) looked at the role of local institutional actors (LIAs) in addressing SIS's poor performance. They focused on local institutional actors in the Limpopo Province, such as cooperatives, government agencies, traditional leaders, irrigation committees, private organizations, local communities, and academic institutions. They looked at how these interactions, inter-organizational structures, information exchange, patterns, similarity, and competitions affect their performance and help bring new technology, business models, and novel mindset to cope with the changing environment and technology. Their results showed that LIA factors significantly influenced the performance of SISs. Their study shows that it works when institutions' intellectual cooperation is reached to achieve a common goal in an institutional context, as predicted by Miller (2018). However, their study focused only on institutional actors as they affect irrigation schemes.

Knowledge about smallholder agriculture support system effectiveness, particularly in Limpopo and elsewhere in South Africa, is limited. Studies such as that of Ubisi et al. (2017) and Maponya and Mpandeli (2012) have investigated the negative impacts of climate change on smallholder farmers. They have also looked at adaptation strategies used and the available support from various institutions to farmers in South Africa. However, even with such studies, there is limited information on whether these institutional interventions and support systems are effective in the Limpopo Province.

There is limited information on the impact of support schemes on farmers' adaptive capacity, especially smallholder oilseed farmers in the Limpopo Province. Therefore, to understand the factors that contribute to supporting smallholder farmer adaptation initiatives, it is critical to investigate the 


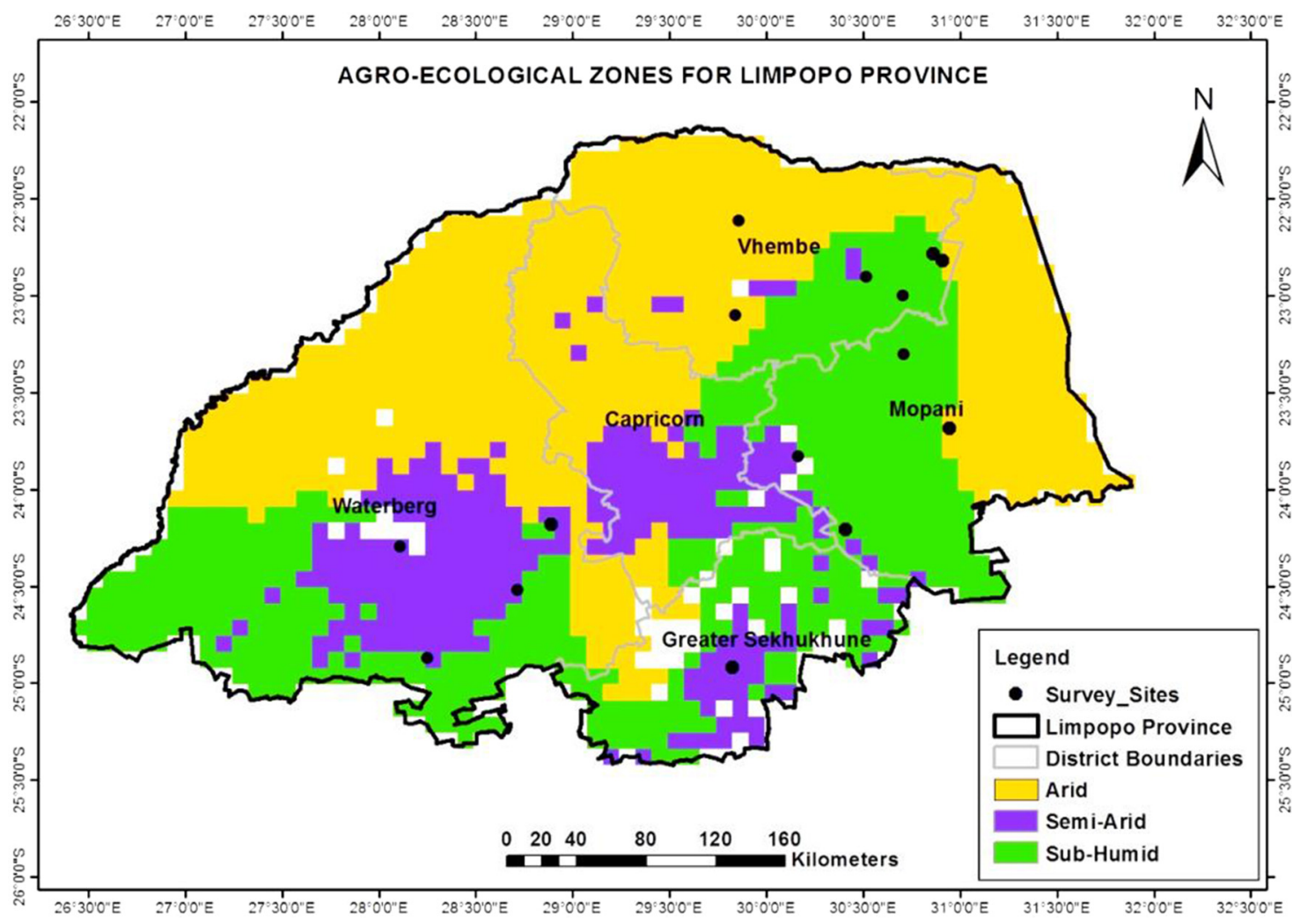

Fig. 1. Agro-ecological zones for Limpopo Province and sample sites. Source: Harvest Choice (2010).

agricultural schemes available to smallholder farmers in Limpopo and the institutions providing them. This will help provide an essential reference and suggestions to formulate suitable agricultural support schemes programmes and implementation thereof. Therefore, this study assesses the institutional support systems available to smallholder oilseed farmers in the summer rainfall areas of Limpopo Province of South Africa. It diagnoses the contribution of various support schemes from these institutions in minimizing the effects of climate change as reflected through crop yields. It is hypothesized that the more support farmers receive, the greater will be their adaptive capacity and the yield thereof.

\section{Materials and methods}

\subsection{Description of the study area}

\subsubsection{Study area}

This study was conducted in the Limpopo Province of South Africa (Fig. 1). Limpopo Province is characterized by low and erratic rainfall patterns characterized by a series of drought and flood events. The uneven distribution of rainfall and high-temperature regimes result in high evaporative water demand and generally low crop water use efficiency (Afful et al., 2015). This results in the loss of most of the surface water resources as non-productive evaporative losses and quick flows resulting from intense rainfall after dry periods into rivers and deep percolation into groundwater reservoirs (Afful and Ayisi, 2016).
The province is made up of distinct climatic zones, namely: the subtropical plateau characterized by a flat elevated interior area, hot and dry; a moderate eastern plateau with warm to hot and rainy summers and cold dry winters; the escarpment region with colder weather because of the altitude and the subtropical Lowveld region with hot-rainy summers and warm-dry winters.

Rainfall in the province occurs mostly between October to April. It ranges from $200 \mathrm{~mm}$ in the hot, dry areas to $1500 \mathrm{~mm}$ in higher rainfall areas, with an average of $450-500 \mathrm{~mm}$ per annum (LDA, 2012). There is a high annual rainfall variability in the province. This variability impacts the water balance of the region, affecting those dependent on agriculture for livelihood.

\subsection{Research approach}

A quantitative research method was used in the study, which employed close-ended questions. Responses were compared across the participants as they were asked uniform questions in the same order to allow for a comparative analysis across respondents in different study sites (Crossman, 2014). The questionnaires were administered to individual smallholder farmers to provide information on the support systems available to them to cope with the climatic and non-climatic challenges and how such support influenced their productivity.

The population who took part in this study comprised smallholder farmers residing in the Limpopo province. A purposive random sample of 600 smallholder farmers took 


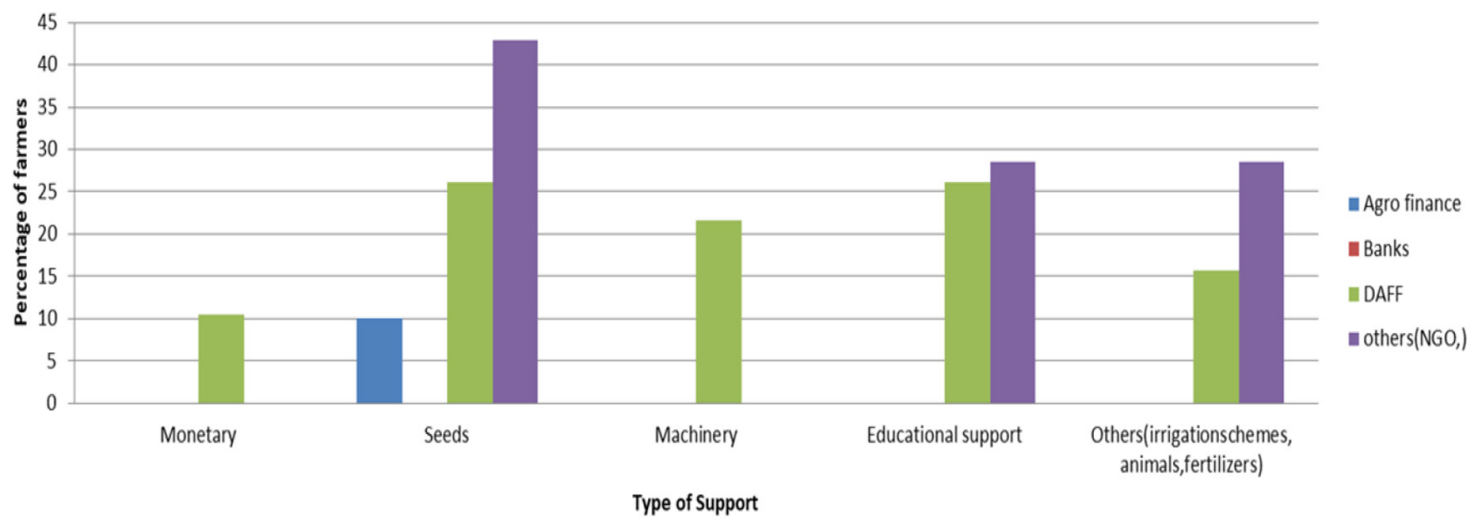

Fig. 2. Source and type of support received by farmers.

part in this study covering different agro-ecological zones. Two hundred participants were targeted from each agro-ecological zone in the province (Fig. 1). A criterion to select the participating sample was set as follows: the respondents were individual smallholder farmers practicing crop production and are solely dependent on rainfall. Relevant departments in each local municipality provided a list fitting the stated criteria, and smallholder farmers were randomly selected based on agroecological zones in Limpopo. Sampling was done in a manner to ensure uniformity and homogeneous characteristics that meet the aims of the study. These characteristics had to adhere to the statistical specifications for accuracy and representativity. A response rate of 100 percent was achieved since the research team interviewed all sampled farmers.

The questions asked aimed at exploring institutional arrangements in place in the Limpopo Province, which focus on assisting farmers in coping with a changing climate. The questionnaire was pre-tested to minimize errors and to restructure unclear questions. Microsoft Excel 2010 statistical package and its add-on Xlstats 2018.2 were used to analyse the data. The coded data provided a general overview of the institutional support that the farmers were receiving. A regression analysis was used to evaluate the impacts of the number of farmers' support types received and the influence on grain yield produced.

\section{Results}

This study examined the role of institutional support in enhancing smallholder oilseed producers' adaptive capacity to the atrocities of the changing climate. This was conducted in Limpopo Province of South Africa, a province affected by climate change impacts, characterized by extreme drought, floods and high temperature (Mosase and Ahiablame, 2018; Mpandeli et al., 2019; Botai et al., 2020). Results show that these smallholder farmers received most of their support (70\%) from the Department of Agriculture, Fisheries and Forestry (DAFF), followed by NGO's (25.6\%) and Agro finance institutions (4.4\%) (Fig. 2). With regards to support from DAFF, $10.4 \%$ of the farmers received monetary benefit, $26.1 \%$ seeds and educational support, $21.6 \%$ machinery and $15.7 \%$ from irrigation schemes, livestock and/or fertilizers. A total of $42.85 \%$ of the farmers received seeds, $28.6 \%$, educational

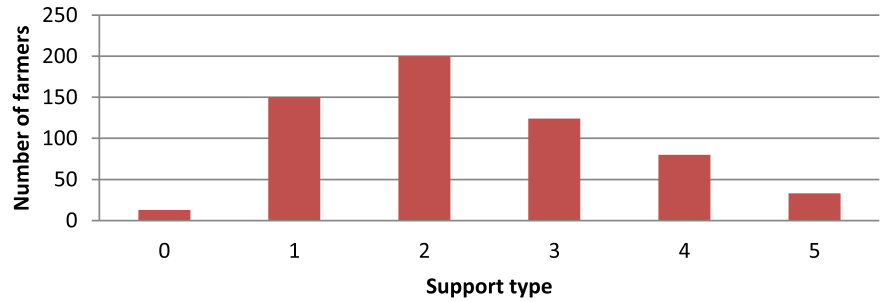

Fig. 3. The total number of support type received by the farmers.

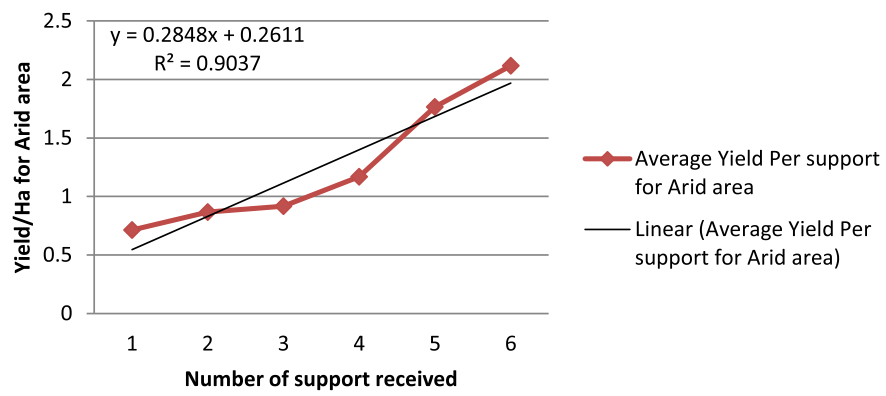

Fig. 4. Yield against the number of supports received in the arid areas of Limpopo.

support and $28.6 \%$ received other support types from NGOs. Most support received by farmers was in the form of seeds $(66.7 \%)$, followed by educational and other support types at $41.7 \%$ (Fig. 2), respectively.

Thirteen farmers did not receive any support, 150 had one support source, 200 had two types of support, 124 had three, 80 had four and 33 had five support types (Fig. 3).

The relationship between the number of supports received per agro-ecological zone (AEZ) and the grain yield produced indicates that the average grain yield increase with an increase in the number of support types received by the farmers across all agro-ecological zones. A strong linear relationship is shown between grain yield and the number of support types received by the farmers (Figs. 4-6). In the arid region, about $90 \%$ of the yield can be explained by the number of supports received (Fig. 4), $89 \%$ in the semi-arid (Fig. 5) and $88 \%$ in the subhumid area (Fig. 6). 
P.N. Kephe et al.: OCL 2021, 28, 14

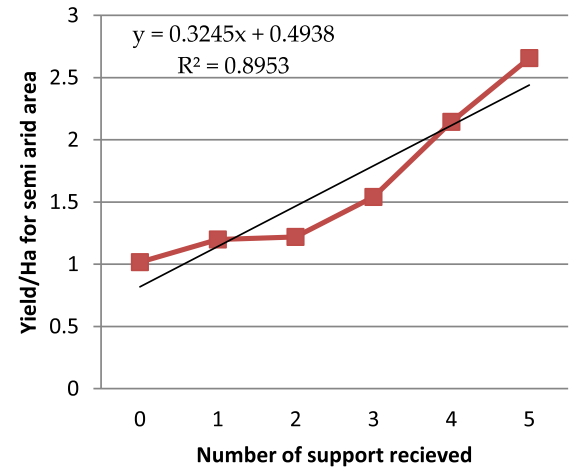

- Average Yeild Per support for semi arid area

L Linear (Average Yeild Per support for semi arid area)

Fig. 5. Yield against the number of supports received in the semi-arid areas of Limpopo.

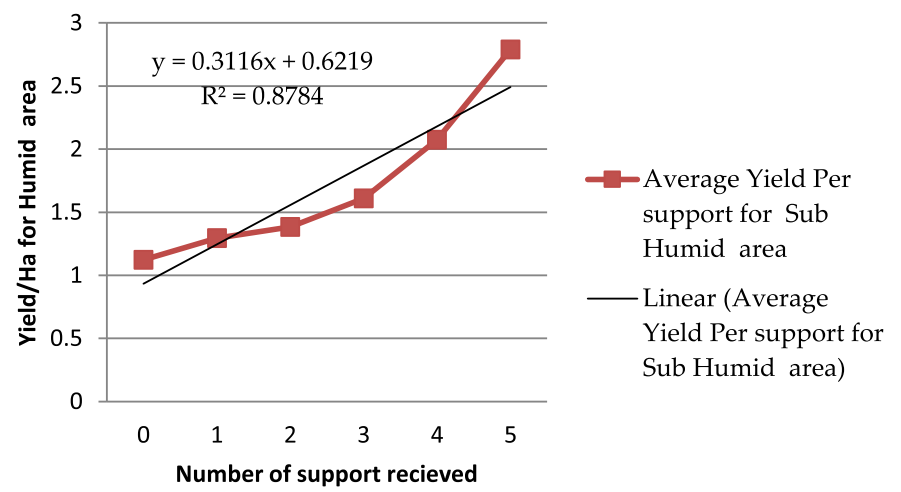

Fig. 6. Yield against the number of supports received in the humid areas of Limpopo.
Table 1. Test of significance.

\begin{tabular}{lc}
\hline Chi-square (Observed value) & 2.215 \\
\hline Chi-square (Critical value) & 24.996 \\
DF & 15 \\
$P$-value & 1.000 \\
Alpha & 0.05 \\
Wilks' G ${ }^{2}$ (Observed value) & 3.151 \\
Wilks' G' (Critical value) & 24.996 \\
DF & 15 \\
$p$-value & 0.999 \\
Alpha & 0.05 \\
\hline
\end{tabular}

Table 2. The measure of sampling adequacy.

\begin{tabular}{lc}
\hline Support types & Values \\
\hline Monetary & 0.538 \\
Seeds & 0.532 \\
Machinery & 0.496 \\
Educational support & 0.692 \\
Others (irrigation schemes, animals, fertilizers) & 0.432 \\
KMO & 0.539 \\
Cronbach's alpha: 0.585 & \\
\hline
\end{tabular}

Table 3. Factor analysis of support received by smallholder farmers in Limpopo.

\begin{tabular}{lrrrrr}
\hline Factor pattern & \multicolumn{1}{c}{$F 1^{\ddagger \neq}$} & \multicolumn{1}{c}{$F 2^{\neq \neq \neq \neq}$} & Initial communality & Final communality & Specific variance \\
\hline Monetary & $\mathbf{0 . 9 0 1}$ & 0.434 & 1.000 & $\mathbf{1 . 0 0 0}$ & $\mathbf{0 . 0 0 0}$ \\
Seeds & $\mathbf{0 . 7 9 7}$ & -0.604 & 1.000 & $\mathbf{1 . 0 0 0}$ & $\mathbf{0 . 0 0 0}$ \\
Machinery & $\mathbf{0 . 7 4 6}$ & -0.665 & 1.000 & $\mathbf{1 . 0 0 0}$ & $\mathbf{0 . 0 0 0}$ \\
Educational support & $\mathbf{0 . 9 9 6}$ & 0.088 & 1.000 & $\mathbf{1 . 0 0 0}$ & $\mathbf{0 . 0 0 0}$ \\
Others (irrigation schemes, animals, fertilizers) & $\mathbf{- 0 . 7 2 9}$ & -0.684 & 1.000 & $\mathbf{1 . 0 0 0}$ & $\mathbf{0 . 0 0 0}$ \\
\hline
\end{tabular}

\subsection{Test of significance of variation in yield response to support types across agro-ecological zones}

Evidence from Table 1 shows a chi-square, $p=1$ which is greater than $\alpha$-value $(0.05)$. Hence, on this basis, the null hypothesis was accepted, and it was established that the samples are statistically different. To reiterate this, the $p$-value for Wilks' $\mathrm{G}^{2}$ is compared with the $\alpha$-value. Given that the $p$-value obtained in the analysis is 0.99 (Tab. 2), which is greater than $\alpha=0.05$, the null hypothesis, which states that the means are independent, is accepted.

\subsection{Principal factors to support adaption amongst smallholder oilseed farmers}

A factor analysis was conducted to determine which of the support was most important for smallholder farmers' adaptation to climate change. The Kaiser-Meyer-Olkin (KMO) (Tab. 2) was used to assess sampling adequacy and evaluation of correlations that are acceptable at values $>0.500$. The KMO value was 0.539 , which confirms that the sample data could be used to perform factor analysis (Tab. 2). The Cronbach alpha was 0.585 , and this suggests that the sample is statistically correlated with high reliability (Tab. 2).

The factor analysis (Tab. 3) showed that educational support was the most crucial factor in farmer's adaptive capacity. This is followed by monetary, seed, and machinery support.

\section{Discussion}

Agriculture, being a critical cornerstone of Limpopo Province's economy, needs to be sustained to ensure the 
continual growth of the area's economy in the era of climate change. Farmers need to be adequately equipped to respond to strategic interventions, which will make them more resilient to climate change. Results from this study reveal that farmers receive various types of support from different stakeholders, sometimes concurrently. Thus, various governmental and nongovernmental institutions have programmes to support farmers, aiming to increase their resilience to climate change. These programmes extend to the following interventions: DAFF's Programme; Comprehensive Agricultural Support Programme (CASP) together with Revitalization of smallholder Irrigation and Schemes (RESIS). The types of support received and their impacts on smallholder farmers in Limpopo province were presented in Table 3. Educational support was ranked as the highest and showed to be a significant input towards farmer's resilience. In assessing the importance of educational support in managing the impacts of climate change by farmers in the Limpopo Province, some studies have indicated that the provision of extension support, including climate variability information, contributed to increased crop yields (Afful et al., 2015; Afful and Ayisi, 2016). Most farmers in rural areas such as those in Limpopo Province are not privy to the most up-todate information on efficient food production practices, costeffective means of implementation, adaptation techniques to a changing climate as well as the proper implementation of these techniques. The question which arises in cases such as those of the resource-poor farmers in Limpopo is, how do they receive the necessary education needed for optimum production and to improve adaptive capacity in a changing climate? A possible solution that has also been cited by Rosegrant and Cline (2003) is that of enhancing farmers' understanding of new techniques and technologies and providing them with any physical resources necessary for implementation. Mwangi and Kariuki (2015) cautioned that farmers' perception of new technologies must also be considered in programmes designed to introduce such technologies to farmers. These approaches can dramatically increase the farmers' productivity level, which can further equip them to adapt to a changing climate.

A critical look at the strategic plan for South African agriculture 2015/16-2019/20 (DAFF, 2015) shows that the national and provincial departments of agriculture are committed to providing extension support to land reform beneficiaries. Extension services are particularly necessary where parcels of land are intensively farmed because they cannot be expanded easily and hence need all the knowledge and improvement in farmers' managerial and technical skills to support their production. The role of agricultural extension services entails disseminating relevant information by extension workers to the farmers, transferring knowledge from researchers to farmers, educating them about decision-making processes, and promoting desirable agricultural development (Msuya et al., 2017). In South Africa, the agricultural extension services serve as an essential link between smallholder farmers and the Department of Agriculture and agricultural extension. It is the primary delivery system for farmers' information in South Africa (Stevens and Van Heerden, 2016). This might explain why most of the farmers' support is from DAFF (Fig. 2). Of the 600 farmers surveyed, only $58.33 \%$ were receiving educational support (Fig. 2). This is a positive increase from the study results by Mpandeli and Maponya (2014), where only 49 percent of farmers received
Extension services. Extension programs aimed at increasing knowledge can increase the chances of adoption of technology (Sasa, 2010; Bonye et al., 2012).

An increase in the frequency of extension visits to impart knowledge could increase productivity and income generation (Ackello-Ogutu, 2011). Again, education and extension training is essential for farmers to adopt new technologies (Oni et al., 2011). This will explain why education was highly positively rated (0.996) in the factor analysis in Table 3 . Education is essential for all the other support types to be appropriately used. For example, with regards to seeds, farmers need to be knowledgeable about the type of seeds they ought to plant and the farm management practices (planting dates, planting density, days to maturity) specific to cultivar types . Furthermore, with regards to machinery, even though it has been indicated that agricultural productivity is closely related to machinery and investments in all aspects of agricultural activity (Stavytskyy and Prokopenko, 2017), it has been shown that investing in agricultural machinery with an aggregate support system (such as increased level of education) has proven not only to be effective but also highly advantageous for agricultural and economic development in general (Stavytskyy and Prokopenko, 2017). Therefore, the inclusion of agricultural extension and further education on machine use are essential for the operationalization of any mechanization and the consequent sustainability of the farming system and mitigation and adaptive measures.

Fertilizer, which is commonly thought to be a significant resource contributing up to $50 \%$ of the potentially output growth (Tomich et al., 2018), does not rank amongst the region's essential production factors. This might result from poor application techniques, insufficient amounts applied, and poor timing of application.

The observed negative prioritizationing of the irrigation schemes can be linked to results from other studies carried out in South Africa, which attributed the poor performance of irrigation schemes to deficiencies in infrastructures as well as poor institutional support (e.g. Machethe and Mollel, 2000; Tlou et al., 2006; Van Averbeke et al., 2011; Fanadzo, 2012).

The results show that smallholder oilseed farmers can increase productivity with adequate access to farmer support services. This, therefore, means that where the farmers receive more support, as shown in Figures 3-6, they tended to have higher yeilds and were able to sustain their production. This line of thought further ties in with the observations of Cherotich et al. (2012), who reported that climate change interventions and support services provide an opportunity for the farmers to withstand the climatic challenges, thereby strengthening their capacity for effective agricultural production.

\subsection{Policy Implications of institutional support}

In South Africa, agricultural support institutions lack a coherent link between the support schemes and programme implementation. In such conditions, the farmer support should be characterized by the farmers' unique situation, so that adaptation, sustainability, and productivity become the primary focus to win the fight against food and livelihood insecurity. Some of the problems of inadequate implementation of schemes are due to the bureaucratic nature and 
procedures within the public sector, which can be limiting and inflexible in nature. Given that such challenges are inherent within this sector, there is a need for the government to review some of their operational procedures in light of their impact on scheme implementation and accessibility to farmers. Some of the difficulties experienced by farmers in accessing support institutions are also due to different working environments within public institutions. Therefore, improvement in support institutions should address the provision of adequate support types that are accessible, comprehensive and quality information that is easily disseminated. Optimizing institutional support to farmers can be achieved by improving institutional performance, increasing the number of support types available to farmers, increasing the relationship between farmerextension-research input/output on the field and focusing on those support areas that enhance the resilience of smallholder farmers. The government should improve implementation of policies that support outreach based on farmer needs such as institutions' ability to provide quality information, technical farm training, and training of utilization of information and communication technologies, regional policies related to the revitalization of support schemes and extension services.

The private sector has become an important alternative and collaborator to public institutions for providing technical inputs, information, training, and organisational support services to smallholder farmers. Agriculture stakeholders in South Africa cannot ignore the role of proper implementation of adequate support schemes to improve farmers' productivity and livelihood. Failure to do so would result in the further deterioration of programmes that offer institutional support and undermine their long-term goals. To continue with a "business as usual" mode could put resources allocated for specific schemes to waste. Instead, support institutions need to determine how to give appropriate supports to smallholder farmers and how public and private institutions can work together in a partnership that will serve long-term societal interests.

The low levels of support received by farmers emphasize similar findings from other studies like Maponya and Mpandeli (2012). Their study showed that at least 74 percent of farmers did not receive any support. This, therefore, calls for the participation of all relevant parties concerned to change this narrative. Both the government and private sectors can improve farmers' productivity by providing resources to support production, providing extensive knowledge for innovation, provision of efficient interventions so that farmers can willingly take decisions and risks in implementing new farming methods and technology.

\section{Conclusions}

The study revealed that, through existing programmes, smallholder oilseed farmers in the Limpopo Province of South Africa receive different forms of support from government and diverse non-governmental institutions aimed at helping farmers to increase their resilience to climate change. These support sources are, however, not coordinated. The factor analysis indicated that educational support is the dominant type of support needed towards enhancing farmers' adaptive capacity, followed by monetary, seed, and machinery forms of support. A strong relation between grain yield and the number of supports received was also evident in the study, irrespective of the agro-ecological zone. Both public and private institutions have significant roles to play in supporting farmers' adaptive capacity to a changing climate in the Limpopo Province. Where possible, the government and nongovernmental institutions should pull resources together and make sure farmers receive adequate support. Based on the findings of the current study, the following recommendations can be put forward:

- Agricultural support institutions fall short in providing sufficient support types and schemes to farmers. Therefore, agriculture support schemes and programmes and agricultural research must remain an integral part of the government strategy to address food insecurity and poverty at the household level.

- Considering the current poor reach of support schemes, there should be more public-private partnerships with better coordination. Some of the public funding could be used to expand support programmes by way of contracting and developing joint programmes. Public institutions should take the lead in connecting these different private and non-governmental institutions and enabling effective communication that can foster partnerships. Identifying potential partners and developing working relationships amongst other agencies should be the main task of extension managers at the provincial, district, and local levels. Development of extension policies and operational guidelines to promote partnerships at the state level would go a long way in reforming support programmes and enhancing farmers' support. There should be a growing awareness, in both the public and private sectors, of the significant benefits that can be derived from such collaborations. New ways must be found to break down barriers and increase communication and trust between the public and private sectors.

- Simultaneously, organizing and grouping farmers with similar circumstances by government and non-governmental actors are needed to enable farmers to benefit from their interaction, easy training, and knowledge sharing. Thus, institutional actors' support schemes must consider the farmer's diversity when offering their services to achieve a common goal.

- Given the multiple roles various public and private support institutions play in assisting farmers, their interaction needs further investigation to reduce conflicts and duplication and better understand how they can benefit the local communities and improve support scheme performance.

\section{Funding}

This work was funded through the University of Limpopo (UL) and the VLIR-UOS collaboration.

Conflicts of interest. The authors declare no conflict of interest. The funders had no role in the design of the study; in the collection, analyses, or interpretation of data; in the writing of the manuscript, or in the decision to publish the results. 


\section{References}

Ackello-Ogutu C. 2011. Managing food security implications of food price shocks in Africa. J Afr Econ 20(suppl 1): i100-i141.

Afful DB, Ayisi KK. 2016. Extension support for grain crop producers under climate variability scenario: implications for extension management in Limpopo province, South Africa. J Agribus Rural Develop 3: 41.

Afful DB, Oluwatayo IB, Kyei KA, Ayisi K, Zwane EM. 2015. Contribution of Public Extension to Food Security of Smallholder Farmers in Limpopo Province, South Africa in an Era of Climate Variability. J Human Ecol 50(3): 205-212.

Agricultural disaster management policy. 2011. South Africa: Agricultural disaster management policy. Limpopo Provincial Government, pp. 1-16. Available from http://www.lda.gov.za/ downloads/disaster_management_policy/agric_disaster_manage ment.pdf (Accessed on 15 March 2018).

Bonye SZ, Alfred KB, Jasaw GS. 2012. Promoting community-based extension agents as an alternative approach to formal agricultural extension service delivery in Northern Ghana. Asian J Agric Rural Develop 2(393-2016-23897): 76-95.

Botai CM, Botai JO, Zwane NN, et al. 2020. Hydroclimatic Extremes in the Limpopo River Basin, South Africa, under Changing Climate. Water 12(12): 3299.

Bureau for Food and Agricultural Policy (BFAP). 2016. Policy brief on the 2015/2016 drought, pp. 1-44. Available from http://www. bfap.co.za/documents/research\%20reports/BFAP Drought $\%$ 20Policy\%20Brief_5\%20February\%202016.pdf (Accessed on 15 March 2018).

Cherotich VK, Saidu OSENI, Bebe BO. 2012. Access to climate change information and support services by the vulnerable groups in semi-arid Kenya for adaptive capacity development. Afr Crop Sci J 20(2): 169-180.

Crossman A. 2014. Level of Measurement. About.com Sociology. Available from http://sociology.about.com/od/Statistics/a/Levelsof-measurement.htm.

Department of Agriculture, Forestry and Fisheries. 2015. 2015/16 to 2019/20 Strategic Plan. Pretoria: Department of Agriculture, Forestry and Fisheries. https://www.daff.gov.za/doaDev/top Menu/DAFF SP \%20complete.pdf.

Harvest Choice. 2010. Available from http://harvestchoice.org/data/ aez-16-class.

Fanadzo M. 2012. Revitalisation of smallholder irrigation schemes for poverty alleviation and household food security in South Africa: A review. Afr J Agric Res 7(13): 1956-1969.

Human Science Research Council (HSRC). 2014. The South African National Health and Nutrition Examination survey, 2012: SANHANES the health and nutrition status of the nation. http://www.hsrc.ac.za/en/research-outputs/view/6493.

International Fund for Agricultural Development (IFAD). 2008. Climate change and the future of smallholder agriculture. How can rural poor people be a part of the solution to climate change? Discussion paper prepared for the Round Table on Climate Change at the Thirty-first session of IFAD's Governing Council, 14 February 2008, Rome, International Fund for Agricultural Development.

Limpopo Department of Agriculture. 2012. The Mapping of Agricultural Commodity Production in the Limpopo Province, South Africa.

Lowder SK, Skoet J, Raney T. 2016. The number, size, and distribution of farms, smallholder farms, and family farms worldwide. World Develop 87: 16-29.
Machethe CL, Mollel NM. 2000. Extension and support services for smallholder agricultural development in South Africa: who is the smallholder farmer? In: At the crossroads: land and agrarian reform in South Africa into the 21st century. Papers from a Conference held at Alpha Training Centre, 26-28 July 1999, Broederstroom, Pretoria, South Africa, Programme for Land and Agrarian Studies (PLAAS), pp. 340-348.

Makhura MT. 2002. Overcoming transaction costs barriers to market participation of smallholder farmers in the Northern Province of South Africa. Doctoral dissertation, University of Pretoria.

Makhura MT. 2002. Overcoming transaction costs barriers to market participation of smallholder farmers in the Northern Province of South Africa. Doctoral dissertation, University of Pretoria.

Maponya P, Mpandeli S. 2012. Climate change and agricultural production in South Africa: Impacts and adaptation options. $J$ Agric Sci 4(10): 48.

Miller S. 2018. Dual use science and technology, ethics and weapons of mass destruction. Springer.

Mnkeni PNS, Chiduza C, Modi AT, et al. 2010. Best management practices for smallholder farming on two irrigation schemes in the Eastern Cape and KwaZulu-Natal through participatory adaptive research. WRC Report No. TT, 478(10), 359.

Mosase E, Ahiablame L. 2018. Rainfall and temperature in the Limpopo river basin, Southern Africa: means, variations, and trends from 1979 to 2013. Water 10(4): 364.

Mpandeli NS. 2006. Coping with climate variability in Limpopo Province. Unpublished PhD thesis, University of Witwatersrand.

Mpandeli S, Maponya P. 2014. Constraints and challenges facing the small scale farmers in Limpopo Province, South Africa. J Agric Sci 6(4): 135.

Mpandeli S, Nesamvuni E, Maponya P. 2015. Adapting to the impacts of drought by smallholder farmers in Sekhukhune District in Limpopo Province, South Africa. J Agric Sci 7(2): 115.

Mpandeli S, Nhamo L, Moeletsi M, et al. 2019. Assessing climate change and adaptive capacity at local scale using observed and remotely sensed data. Weather Clim Extrem 26: 100240.

Msuya CP, Annor-Frempong FK, Magheni MN, et al. 2017. The role of agricultural extension in Africa's development, the importance of extension workers and the need for change. Int J Agric Ext 5(1): $51-58$.

Mwadzingeni L, Mugandani R, Mafongoya P. 2020. Localized Institutional Actors and Smallholder Irrigation Scheme Performance in Limpopo Province of South Africa. Agriculture 10(9): 418.

Mwangi M, Kariuki S. 2015. Factors determining adoption of new agricultural technology by smallholder farmers in developing countries. J Econ Sustain Develop 6(5).

Ncube BL. 2017. Institutional support systems for small-scale farmers at new forest Irrigation Scheme in Mpumalanga, South Africa: constraints and opportunities. South Afr J Agric Ext 45(2): 1-13.

Oni SA, Maliwichi LL, Obadire OS. 2011. Assessing the contribution of smallholder irrigation to household food security, in comparison to dryland farming in Vhembe district of Limpopo province, South Africa. Afr J Agric Res 6(10): 2188-2197.

Osbahr H, Twyman C, Adger WN, Thomas DS. 2010. Evaluating successful livelihood adaptation to climate variability and change in southern Africa. Ecol Soc 15(2).

Rosegrant MW, Cline SA. 2003. Global food security: challenges and policies. Science 302(5652): 1917-1919.

Sasa SR. 2010. Mulches in smallholder maize systems in the Limpopo Province of South Africa: untangling the effects of $\mathrm{N}$ through experimentation and simulation (Msc dissertation). 
Stavytskyy A, Prokopenko O. 2017. Investments in agricultural machinery and its efficiency in Ukraine. Ekonomika (Economics) 96(1): 113-130.

Stevens JB, van Heerden PS. 2016. Knowledge brokering and dissemination of irrigation management guidelines for training of extension advisors. Report No. KV, 356, 16.

Thamaga-Chitja JM, Morojele P. 2014. The context of smallholder farming in South Africa: Towards a livelihood asset building framework. J Human Ecol 45(2): 147-155.

Tlou T, Mosaka D, Perret S, Mullins D, Williams CJ. 2006. Investigation of different farm tenure systems and support structure for establishing Smallholdersmallholder irrigation farmers in long term viable conditions. Water Research Commission Report (1353/1): 06.

Tomich TP, Kilby P, Johnston BF. 2018. Transforming agrarian economies: Opportunities seized, opportunities missed. Cornell University Press.
Ubisi NR, Mafongoya PL, Kolanisi U, Jiri O. 2017. Smallholder farmer's perceived effects of climate change on crop production and household livelihoods in rural Limpopo province, South Africa. Change Adapt Soc-Ecol Syst 3(1): 27-38.

United Nations Development Programme (UNDP) (United Nations). 2015. Draft Outcome Document of the United Nations Summit for the Adoption of the Post-2015 Development Agenda, A/69/ L.85. http://www.un.org/ga/search/view_doc.asp?symbol=A/69/ L. 85\&; Lang=E.

Van Averbeke W, Denison J, Mnkeni PNS. 2011. Smallholder irrigation schemes in South Africa: A review of knowledge generated by the Water Research Commission. Water SA 37(5): 797-808.

van Koppen B, Nhamo L, Cai X, et al. 2017. Smallholder irrigation schemes in the Limpopo Province, South Africa (Vol. 174). International Water Management Institute (IWMI).

Cite this article as: Kephe PN, Petja BM, Ayisi KK. 2021. Examining the role of institutional support in enhancing smallholder oilseed producers' adaptability to climate change in Limpopo Province, South Africa. OCL 28: 14. 